\title{
A NECESSIDADE DE DIÁLOGOS ENTRE A DOUTRINA E A JURISPRUDÊNCIA NO DIREITO CIVIL REFLEXÕES SOBRE O XV ENCONTRO DOS GRUPOS DE PESQUISAS EM DIREITO CIVIL - SÃO PAULO - 2017
}

Flávio Tartuce*

\begin{abstract}
Sumário: 1. Primeiras palavras - 2. Tutela da pessoa humana. O "direito de não saber" e seus limites - 3. Técnica de ponderação e responsabilidade civil - 4. Abusividades nos contratos imobiliários de aquisição de imóveis na planta -5 . Direitos reais na contemporaneidade. O enquadramento da multipropriedade imobiliária 6. A parentalidade socioafetiva após a decisão do STF - 7. O reconhecimento da inconstitucionalidade do art. 1.790 do Código Civil - Conclusōes - Referências.
\end{abstract}

\section{PRIMEIRAS PALAVRAS}

Entre os dias $1^{\circ}$ e 3 de junho de 2017 ocorreu na cidade de São Paulo, no Largo de São Francisco, o XV Encontro dos Grupos de Pesquisas em Direito Civil, reunindo cerca de cem professores e pesquisadores ligados às Faculdades de Direito da UERJ, da UFPR, da UFPE e da USP. O evento teve a liderança dos Professores Anderson Schreiber, Eroulths Cortiano Junior, Paulo Luiz Netto Lôbo e Giselda Maria Fernandes Novaes Hironaka, ligados a tais instituiçôes, respectivamente.

Doutor em Direito Civil pela USP. Mestre em Direito Civil Comparado pela PUC-SP. Professor Titular permanente do programa de mestrado e doutorado da FADISP. Professor e coordenador dos cursos de pós-graduação lato sensu da EPD. Membro do Instituto Brasileiro de Direito Civil (IBDCIVIL). Advogado, parecerista e consultor jurídico. 
O evento foi estruturado em seis painéis ou mesas, tratando dos seguintes temas: a) tutela da pessoa humana; $b$ ) novos paradigmas da responsabilidade civil; c) contratos; $d$ ) titularidades; $e$ ) Direito de Família; e $f$ ) Direito das Sucessões. Tive a honra de ser nomeado pela Professora Giselda Hironaka, coordenadora-geral do encontro, como responsável pela metodologia a ser aplicada e, assim, pensei em trazer para a aplicação acadêmica algo que sempre pensei como necessário: o diálogo entre a doutrina e a jurisprudência no âmbito do Direito Privado. Tendo aceitado de imediato a incumbência para cada um dos painéis, escolhi um recente julgado de relevo na contemporaneidade do Direito Civil Brasileiro.

Para o painel de tutela da pessoa humana, o acórdão escolhido e abordado foi o julgamento prolatado pela Terceira Turma do Superior Tribunal de Justiça no Recurso Especial n. 1.195.995/SP, no ano de 2011. Trata-se de ação indenizatória proposta em face de prestador de serviços médicos e ambulatoriais, que entregou um exame HIV positivo que não foi solicitado pelo cliente, pois o requerido pelo médico do paciente era o $\mathrm{HCV}$, relativo à hepatite $\mathrm{C}$.

No painel relacionado à responsabilidade civil, analisou-se o julgamento do Agravo Regimental no Agravo em Recurso Especial n. 127.467, originário de São Paulo e do ano de 2016. O decisum abordou ação indenizatória proposta por procuradora federal em face do jornal Folha de S.Paulo e do colunista Elio Gaspari, diante de supostas ofensas feitas em uma de suas colunas, relativa à hipótese fática que ficou conhecida como "Casa da Morte".

Para a abordagem do Direito Contratual, selecionei o acórdão da mesma Corte, em incidente de recursos repetitivos e pela sua Segunda Seção, a respeito da abusividade ou não da comissão de corretagem e da taxa SATI (Serviço de Assessoria Técnica Imobiliária) nos contratos imobiliários de aquisição de imóveis na planta (por todos os três julgamentos, foi debatido o REsp 1.5995.11/SP, de Relatoria do Ministro Paulo de Tarso Sanseverino, julgado em 24 de agosto de 2016).

Para o painel de titularidades ou sobre Direito das Coisas, o decisum discutido disse respeito ao enquadramento ou não da multipropriedade imobiliária presente no "time-sharing" como direito real, o que foi analisado pelo Superior Tribunal de Justiça no ano de 2016 (STJ, REsp 1.5461.65/SP, Relator o Ministro Ricardo Villas Bôas Cueva, Relator para o acórdão Ministro João Otávio de Noronha, Terceira Turma, julgado em 26.04.2016, DJe 06.09.2016). A escolha foi óbvia, diante da citação, na ementa do julgado, da doutrina do Professor Gustavo Tepedino, um dos ícones acadêmicos das escolas que ali se encontravam.

Encerrando o nosso encontro, apontei dois julgados do Supremo Tribunal Federal, de grande impacto jurídico, sobre o Direito de Família e das Sucessóes. 
Em Direito de Família, o julgamento a respeito da repercussão geral da parentalidade socioafetiva, do ano de 2016, publicado no Informativo n. 840 da Corte. Em Sucessão, foi debatido o acórdão sobre a inconstitucionalidade do art. 1.790 do Código Civil de 2002, a respeito da sucessão do companheiro (constante do Informativo n. 864 do STF).

Neste texto pretendo trazer minha visão geral sobre os debates que ocorreram no encontro, e sobre como se deu o desenvolvimento da visão doutrinária sobre as ementas selecionadas, na busca da sempre necessária interação entre a doutrina e a jurisprudência, muitas vezes esquecida ou abandonada por estudiosos e julgadores. Sobre esse diálogo, a propósito, naquele momento do encontro já estava em desenvolvimento obra que propõe tais interações, recentemente lançada. ${ }^{1}$

\section{TUTELA DA PESSOA HUMANA. O "DIREITO DE NÃO SABER" E SEUS LIMITES}

O primeiro painel do encontro foi composto pelos Professores Thamis Dalsenter, Taysa Schiocchet, Joyceane Bezerra e João Ricardo Brandão Aguirre, cabendo a mim a presidência dos trabalhos, inclusive como debatedor. Como já mencionei, o julgado escolhido foi o julgamento do Superior Tribunal de Justiça no Recurso Especial n. 1.195.995/SP, em ação movida por consumidor de serviços médicos-laboratoriais em face da Sociedade Beneficente Israelita Hospital Albert Einstein. Argumentou o autor da demanda que, atendendo a prescrição médica, solicitou ao hospital a realização dos seguintes exames: hemograma, creatinina, glicemia jejum, glicemia pós-prandial, Hb glicosilada, ácido úrico, colesterol total e frações, triglicérides, gama GT, glicoproteína ácida, T4 livre, TSH, anti-HCV e HBSAG. Entretanto, sem que houvesse qualquer solicitação de sua parte ou de seu médico, foi realizado exame anti-HIV, cujo resultado foi entregue positivo.

Segundo sustentou o requerente da ação de reparação de danos, "a atitude negligente do réu em relação ao autor proporcionou a este último enorme dano, tanto de ordem material e moral, notadamente pela manifesta violação a sua intimidade". O pleito foi julgado improcedente na primeira e na segunda instância do Tribunal de Justiça de São Paulo, sob o argumento principal da ausência de nexo causal entre a conduta do hospital e do laboratório e o dano causado, pois a doença decorreu de conduta da própria vítima (culpa ou fato exclusivo do consumidor).

1 A obra referenciada é coordenada com o Ministro Luis Felipe Salomão (Direito civil: diálogos entre a doutrina e a jurisprudência. São Paulo: Atlas, 2018). 
No âmbito do Superior Tribunal de Justiça, a relatora sorteada, Ministra Nancy Andrighi, acabou por acatar o pedido, condenando o laboratório ao pagamento do montante de $\mathrm{R} \$ 15.000,00$ (quinze mil reais), a título de danos morais. Como argumentos principais, deduziu a julgadora pela presença da responsabilidade objetiva do prestador de serviços, com fundamento no art. 14 do Código de Defesa do Consumidor e nos arts. 927, parágrafo único, e 931 do Código Civil. Entendeu, ainda, que houve agressão à intimidade do requerente, diante da investigação abusiva da vida alheia e da divulgação não solicitada de informações. ${ }^{2}$

Entretanto, essa forma de julgar os fatos restou vencida pelos votos dos Ministros Massami Uyeda, Sidnei Beneti, Paulo de Tarso Sanseverino e Vasco Della Giustina. Para o primeiro julgador, cujo voto acabou prevalecendo para os fins de composição da ementa do acórdão, o direito à intimidade, como qualquer outro direito individual, não é absoluto, devendo ser ponderado em face de outros direitos ou valores, especialmente aqueles previstos no Texto Maior. Nesse contexto de análise, consta do aresto que "o direito de o indivíduo não saber que é portador do vírus HIV (caso se entenda que este seja um direito seu, decorrente da sua intimidade), sucumbe, é suplantado por um direito maior, qual seja, o direito à vida, o direito à vida com mais saúde, o direito à vida mais longeva e saudável”. Por isso, ainda segundo o Ministro Massami Uyeda, mesmo que o paciente não tivesse interesse ou não quisesse saber da enfermidade que o acometia, a informação que lhe foi fornecida não teve o condão de ofender a sua intimidade, pois se deve assegurar a proteção de um direito maior, qual seja, o direito à vida e à saúde hígida.

Além dessa ponderação, feita do ponto de vista individual e dos direitos do próprio demandante, foram considerados os interesses de terceiros de que o portador do vírus HIV se cuide e se trate. Por fim, o Ministro Ueda asseverou que o Estado vem incentivando, por meio de políticas públicas, que as pessoas façam o

2 Merecem destaque as seguintes palavras da Relatora, Ministra Nancy Andrighi: "Neste processo, o direito à intimidade do recorrente foi violado quando da realização de exame não autorizado, o que causou indevida invasão na esfera privada do recorrente (investigação abusiva da vida alheia). É irrelevante, portanto, o fato de que o resultado do exame não foi divulgado a terceiros. Por mais que se possa adotar a presunção de que a constatação da doença pelo recorrido lhe propiciou melhores condições de tratamento, esse fato, por si só, não retira a ilicitude de sua conduta - negligente - de realizar exame não autorizado nem pedido em favor do recorrente. Acrescente-se que a intimidade abrange o livre-arbítrio das pessoas em querer saber ou não algo afeto unicamente à sua esfera privada. Vale dizer: todos têm direito de esconder suas fraquezas, sobretudo quando não estão preparadas para encarar a realidade” (STJ, REsp 1.195.995/SP, Rel. Min. Nancy Andrighi, Rel. p/acórdão Ministro Massami Uyeda, Terceira Turma, julgado em 22.03.2011, DJe 06.04.2011). 
exame anti-HIV como uma das principais formas de prevenção e controle da disseminação do vírus. Sendo assim, atribuir o pagamento de uma indenização naquele caso concreto seria uma negação dessas políticas, configurando uma indevida sobreposição de um direito individual sobre o interesse público.

O Ministro Beneti seguiu essa fundamentação, acrescentando ainda: a) a ausência de vício ou defeito do serviço, com base no Código de Defesa do Consumidor; b) que, graças ao equívoco laboratorial, o autor pôde iniciar o tratamento da doença, antecipando os seus cuidados e $c$ ) que, se o hospital agisse de maneira diversa, poderia igualmente responder por danos morais. O Ministro Sanseverino filiou-se a essas premissas, destacando os benefícios não só ao paciente no tratamento precoce como a terceiros, para evitar a propagação da doença a outras pessoas. Por fim, expressou o Ministro Vasco Della Giustina: "o caso é importante, e os posicionamentos são muito aprofundados. Entendo que a Sra. Ministra Nancy Andrighi tem bons argumentos. Mas considero que o eminente Ministro Massami foi feliz, quando lembrou do cotejo entre dois princípios: o da vida e o da intimidade. Qual deve prevalecer?".

Como se pode notar pela divergência e pela argumentação, o caso era de difícil julgamento e a divisão de pensamento acabou também se refletindo na mesa de debates do nosso encontro. As Professoras Thamis Dalsenter, Taysa Schiocchet e Joyceane Bezerra filiaram-se ao entendimento da Ministra Nancy Andrighi, especialmente na afirmação de que o direito à intimidade deve prevalecer em casos semelhantes. Para elas, haveria, de fato, um direito de não saber do paciente na hipótese fática descrita, o que justificaria o pleito indenizatório. ${ }^{3}$

O Professor João Ricardo Brandão Aguirre seguiu a posição majoritária do julgamento do Superior Tribunal de Justiça, principalmente pelo fato de não ter havido fato do serviço, previsto como ilícito indenizante no art. 14 do Código de Defesa do Consumidor, uma vez que o exame apenas condizia com a verdade. Acompanhei essa argumentação, sendo certo que foi inevitável o debate a respeito da ponderação dos interesses e direitos fundamentais envolvidos, de um lado a vida e a saúde do outro a intimidade e a privacidade.

Esse primeiro painel já demonstrou que a técnica da ponderação - desenvolvida na Alemanha por Alexy e positivada à brasileira pelo art. 489, $\$ 2^{\circ}$, do CPC/2015 - é um mecanismo eficiente para resolver os dilemas práticos do Direito Civil, o

Sobre a existência desse direito, como faceta da privacidade e intimidade: LOPES, Lucas Miotto. Eu não quero saber! Uma defesa do direito de não saber como independente do direito à privacidade. Revista Direito, Estado e Sociedade, Rio de Janeiro: PUCRJ, p. 82-97, 2014. 
que também foi amplamente discutido na mesa seguinte, apesar de um certo ceticismo verificado na sua utilização.

\section{TÉCNICA DE PONDERAÇÃO E RESPONSABILIDADE CIVIL}

O segundo painel do XV Encontro dos Grupos de Pesquisas em Direito Civil tratou da responsabilidade civil e de seus novos paradigmas, sendo composto pelos Professores Raul Murad, Pablo Malheiros da Cunha Frota, Marcos Ehrhardt Jr. e Romualdo Baptista dos Santos. A presidência dos trabalhos foi da Professora Elisa Cruz, também responsável pelos debates.

O acórdão selecionado dizia respeito a notícia veiculada pelo Jornal Folha de S.Paulo, pelo jornalista Elio Gaspari, a respeito de uma procuradora da Fazenda Nacional que, em contestação apresentada pela União em ação proposta por vítima da tortura praticada durante a ditadura militar, argumentou pela necessidade de se exigir a identificação dos responsáveis pelas nefastas práticas dentro da chamada "Casa da Morte", localizada em Petrópolis, Estado do Rio de Janeiro (STJ, Ag. Rg. no AREsp 127.467/SP, 4a Turma, Rel. Min. Marco Buzzi, Rel. p/acórdão Ministro Luis Felipe Salomão, j. 17.05.2016, DJe 27.06.2016). Vejamos os trechos principais da notícia veiculada pelo colunista, para as devidas reflexōes e análise jurídica:

O médico do DOI deixou uma aula para a procuradora Zandonade.

A procuradora da Fazenda Nacional Adriana Zandonade quer inaugurar um novo capítulo na história dos direitos humanos no Brasil. Ela meteu-se numa história comprida e vale a pena contá-la desde o início.

No dia 5 de maio de 1971 a cidadã Inês Etienne Romeu, quadro de chefia da organização terrorista VAR-Palmares, foi presa em São Paulo pelo delegado Sérgio Fleury. Três dias depois, tendo passado pelo Hospital Central do Exército, no Rio, foi levada para uma casa em Petrópolis (rua Artur Barbosa, 668, propriedade de Mario Lodders). Lá ficou até o dia 11 de agosto. Foi sistematicamente torturada e, por duas vezes, estuprada.

Tornou-se a única pessoa a sair viva daquilo que mais tarde viria a se chamar Casa da Morte. Era um aparelho clandestino do Centro de Informações do Exército, tripulado por oficiais no exercício burocrático de suas funções. Pelas contas de Inês, lá foram mortas pelo menos quatro pessoas.

Atualmente, Inês Etienne Romeu está na Justiça, pedindo que se reconheça que foi mantida em cárcere privado por torturadores a serviço do governo da época. Não quer mais nada. Não está pedindo indenização pelo que lhe fizeram.

A doutora Zandonade sustentou que a denúncia de tortura e cárcere privado não se sustenta porque Inês "nem sequer identifica" as pessoas que a mantiveram em cativeiro. Foi clara: "caberia à requerente indicar com clareza quem é o autor dos atos de tortura, incumbindo-lhe produzir a prova”. 
Beleza. Nesse caso, não desapareceu ninguém na guerrilha do Araguaia.

Primeiro, porque o Exército jamais admitiu a sua existência. Segundo, porque os desaparecidos desapareceram. Da mesma forma, ninguém pode dizer que foi torturado no DOI-Codi, a menos que traga a identidade do torturador e o livro de ponto do calabouço.

Os procuradores são pagos para defender os interesses do Estado, mas qualquer vestibulando de direito sabe que isso não significa defender crimes praticados pelos governantes.

(...)

Uma coisa é certa. A doutora Zandonade conseguiu entrar para a pobre história dos direitos humanos nacionais. Não há por que duvidar de que ostentará a sua contestação ao caso de Inês Etienne como um indicador de sua competência profissional.

A veiculação da notícia transcrita motivou a propositura de ação pela procuradora contra o veículo de comunicação e o colunista. Mais uma vez houve divergência na Corte Superior sobre o direito de indenização a favor da procuradora federal nesse julgamento. O Ministro Marco Buzzi entendeu que o recurso interposto pelos réus não mereceria prosperar, por não atender a requisitos procedimentais, o que geraria a confirmação da procedência da demanda.

Porém, superados tais aspectos instrumentais, o Ministro Luis Felipe Salomão concluiu pela ausência de ofensa a direito da personalidade, pois a crítica foi formulada dentro dos limites da garantia de liberdade de imprensa, tendo em vista o uso da técnica da ponderação. Como destacou em seu voto, afirmação que apoio, "as pessoas consideradas públicas estão sujeitas a maior exposição e suscetíveis a avaliações da sociedade e da mídia, especialmente os gestores públicos de todas as esferas de poder, mesmo quando envolvidos em processos judiciais - que, em regra, não correm em segredo de justiça - como partes, procuradores ou juízes" (STJ, Ag. Rg. no AREsp 127.467/SP, 4a Turma, Rel. Min. Marco Buzzi, Rel. p/acórdão Min. Luis Felipe Salomão, j. 17.05.2016, DJe 27.06.2016). Assim, houve a valorização do papel da imprensa com mero animus narrandi e criticandi.

Penso que o acórdão seguiu a linha jurisprudencial de tratar a liberdade de expressão como um superdireito, afirmação confirmada com a leitura e análise do julgamento do Supremo Tribunal Federal sobre as biografias não autorizadas. Como é notório, foi proposta uma ação direta de inconstitucionalidade perante o Supremo Tribunal Federal contra os arts. 20 e 21 do Código Civil, pela Associação Nacional dos Editores de Livros (ADIn 4.815, intentada em julho de 2012). O pedido da ação era no sentido de ser reconhecida a inconstitucionalidade parcial dos arts. 20 e 21 do CC/2002, sem redução de texto, "para que, mediante interpretação conforme a Constituição, seja afastada do ordenamento jurídico brasileiro a 
necessidade do consentimento da pessoa biografada e, a fortiori, das pessoas retratadas como coadjuvantes (ou de seus familiares, em caso de pessoas falecidas) para a publicação ou veiculação de obras biográficas, literárias ou audiovisuais, elaboradas a respeito de pessoas públicas ou envolvidas em acontecimentos de interesse coletivo". A Suprema Corte Brasileira acabou por julgar conforme foi requerido pela associação-autora.

A questão de tratar-se ou não de um superdireito, a prevalecer sobre qualquer outro, foi amplamente debatida no painel do nosso evento. Acrescente-se que, na VIII Jornada de Direito Civil, em abril de 2018, aprovou-se proposta doutrinária de Anderson Schreiber, no sentido de que não se pode afirmar que a liberdade de expressão sempre prevalecerá sobre a tutela da intimidade, da vida privada ou do segredo. Conforme o Enunciado n. 613 do Conselho da Justiça Federal, "a liberdade de expressão não goza de posição preferencial em relação aos direitos da personalidade no ordenamento jurídico brasileiro". Em certo sentido, o nosso encontro antecipou os debates para a tese que culminou no enunciado doutrinário.

Reitere-se que, assim como se deu no painel anterior, houve também um profundo debate sobre a aplicação da técnica da ponderação no âmbito do Direito Civil Brasileiro, o que reflete na análise da responsabilidade civil e da imputação do dever de indenizar. Como é notório, a técnica de ponderação - positivada pelo Novo CPC - é um dos artifícios metodológicos para a solução de casos concretos utilizados pela escola do Direito Civil Constitucional, linha seguida pelos pesquisadores que participaram do encontro.

Apesar do ceticismo e das críticas de Pablo Malheiros no painel, acabou por se concluir que a técnica de ponderação deve ser utilizada nos casos de colisão entre a liberdade de expressão e os direitos da personalidade, sendo o meio mais adequado para resolver os conflitos entre tais direitos, imputando-se ou não o dever de indenizar. Na mesma linha, a propósito, vale lembrar o teor do Enunciado n. 279, aprovado na IV Jornada de Direito Civil, evento de 2006: "a proteção à imagem deve ser ponderada com outros interesses constitucionalmente tutelados, especialmente em face do direito de amplo acesso à informação e da liberdade de imprensa. Em caso de colisão, levar-se-á em conta a notoriedade do retratado e dos fatos abordados, bem como a veracidade destes e, ainda, as características de sua utilização (comercial, informativa, biográfica), privilegiando-se medidas que não restrinjam a divulgação de informações".

Por fim, restou pacificado entre os presentes na mesa e os debatedores que participaram das discussóes que a ponderação deve ser melhor conduzida pelos julgadores brasileiros e, assim como concebida por Alexy, deve ser efetivada com o 
uso de critérios objetivos e a necessária fundamentação, como aliás consta do próprio Código de Processo Civil de 2015. ${ }^{4}$

\section{ABUSIVIDADES NOS CONTRATOS IMOBILIÁRIOS DE AQUISIÇÃO DE IMÓVEIS NA PLANTA}

O painel sobre Direito dos Contratos foi presidido por José Fernando Simão, contando com a participação dos Professores Daniel Bucar Cervasio, Luciana Xavier, José Barros e Alexandre Junqueira Gomide como expositores. A temática analisada foi a relativa aos contratos de aquisição de imóveis na planta, notadamente os entendimentos da Segunda Seção do Superior Tribunal de Justiça sobre as cobranças da taxa de corretagem e da taxa SATI (Serviço de Assessoria Técnica Imobiliária).

A conclusão do painel, unânime entre seus participantes e de forma bem incisiva, foi no sentido de que ambos os valores não poderiam ser cobrados dos consumidores e adquirentes dos imóveis, fazendo com que fosse cabível a sua devolução em dobro, incidindo plenamente a regra do parágrafo único do art. 42 do Código de Defesa do Consumidor. ${ }^{5}$

4 Sobre a correta forma de conduzir a ponderação, veja-se: ALEXY, Robert. Teoria dos direitos fundamentais. São Paulo: Malheiros, 2008.

5 Aponte-se que, concluindo dessa forma, já existiam julgados estaduais, caso do seguinte, do Tribunal Paulista: "Verbas de assessoria imobiliária. Devolução dos valores. Possibilidade, segundo o Enunciado n. 38.3 desta Câmara, exibindo as vendedoras legitimidade para a restituição: 'O adquirente que se dirige ao estande de vendas para a aquisição do imóvel não responde pelo pagamento das verbas de assessoria imobiliária (corretagem e taxa SATI). É da responsabilidade da vendedora o custeio das referidas verbas, exibindo legitimidade para eventual pedido de restituição'. Devolução em dobro, entretanto, afastada. Má-fé não demonstrada. Incidência do enunciado pela Súmula n. 159 do STF. 5. Despesas de condomínio e taxas de IPTU exigidas antes da entrega das chaves. Impossibilidade, segundo o Superior Tribunal de Justiça: 'Para efeitos do art. 543-C do CPC, firmam-se as seguintes teses: A) O que define a responsabilidade pelo pagamento das obrigações condominiais não é o registro do compromisso de compra e venda, mas a relação jurídica material com o imóvel, representada pela imissão na posse pelo promissário comprador e pela ciência inequívoca do condomínio acerca da transação'. Devolução em dobro dos valores, entretanto, afastada. Ausência de má-fé na realização da cobrança. 6 . Indenização por danos materiais. Arbitramento de lucros cessantes. Admissibilidade, segundo o entendimento do STJ também adotado pela Câmara (Enunciado n. 38.5). Necessidade, entretanto, de arbitramento da verba no equivalente ao aluguel do imóvel a contar da data de constituição das vendedoras em mora até a efetiva entrega das chaves. Apuração do valor devido em liquidação de sentença. 7. Indenização por danos morais. Acolhimento do pleito indenizatório. Frustração relacionada à aquisição do imóvel que importou em lesão extrapatrimonial” (TJSP, Apelação Cível 0006490-36.2013.8.26.0114, Acórdão 8762314, Campinas, Terceira Câmara de Direito Privado, Rel. Des. Donegá Morandini, j. 31.08.2015, DJeSP 04.09.2015). 
Entretanto, como já adiantei, a Segunda Seção do Superior Tribunal de Justiça acabou por concluir, no ano de 2016, pela possibilidade de cobrança da taxa de corretagem, desde que exista uma prévia, clara e ostensiva comunicação aos adquirentes. Como constou do julgado que foi analisado no encontro, há "validade da cláusula contratual que transfere ao promitente-comprador a obrigação de pagar a comissão de corretagem nos contratos de promessa de compra e venda de unidade autônoma em regime de incorporação imobiliária, desde que previamente informado o preço total da aquisição da unidade autônoma, com o destaque do valor da comissão de corretagem" (STJ, REsp 1.599.511/SP, Rel. Min. Paulo de Tarso Sanseverino, 2a Seção, j. 24.08.2016, DJe 06.09.2016).

$\mathrm{Na}$ mesma oportunidade, entendeu-se no Tribunal da Cidadania que a taxa SATI seria abusiva, sendo cabível a sua repetição ou devolução de forma simples, mas não em dobro. Sobre o prazo prescricional, a conclusão do Tribunal foi no sentido da subsunção do prazo de prescrição de três anos, previsto para as pretensões fundadas no enriquecimento sem causa, a contar da celebração do contrato (art. 206, $\$ 3^{\circ}$, inc. IV, do Código Civil).

Todos os presentes no encontro lamentaram o teor da decisão. Como restou novamente pacificado entre os juristas presentes, do art. 722 do Código Civil retira-se a dedução no sentido de que aquele que contrata o corretor, e obtém da sua atuação o resultado útil contratual, é o responsável pelo pagamento da sua comissão. ${ }^{6}$ Sobre a possibilidade de transferir tais montantes aos adquirentes - enquadrados como consumidores na grade maioria das situações concretas e em regra -, foi pontuado tratar-se de uma cláusula abusiva, por força do art. 51, inc. IV, do Código de Defesa do Consumidor, por colocar o consumidor em posição manifestamente desproporcional. Haveria, assim, uma cláusula lesão.

Mesmo não se tratando de contrato de consumo - como ocorre nos imóveis adquiridos para investimento -, a abusividade dessa imposição seria retirada do art. 424 do Código Civil, por se tratar de negócio de adesão, em que não há margem para debate do teor das cláusulas contratuais. Conforme esse comando, nos contratos de adesão são nulas de pleno direito as cláusulas que impõem ao aderente a renúncia antecipada a um direito que resulte da natureza do negócio. Na hipótese, os adquirentes-aderentes renunciaram ao direito de não pagar a taxa de corretagem, o que é imposto pela regra geral a quem contrata ou busca os serviços dos corretores,

6 CC/2002. "Art. 722. Pelo contrato de corretagem, uma pessoa, não ligada a outra em virtude de mandato, de prestação de serviços ou por qualquer relação de dependência, obriga-se a obter para a segunda um ou mais negócios, conforme as instruções recebidas.” 
ou seja, às construtoras. Como foi desenvolvido e pontuado em nosso encontro, essa inversão do pagamento conduz claramente ao enriquecimento sem causa das construtoras.

Frise-se que restou igualmente pacificado entre os pesquisadores presentes no evento que a repetição de indébito deveria ser em dobro, para os dois valores tidos como abusivos, aplicando-se o art. 42, parágrafo único, da Lei n. 8.078/1990, in verbis: "o consumidor cobrado em quantia indevida tem direito à repetição do indébito, por valor igual ao dobro do que pagou em excesso, acrescido de correção monetária e juros legais, salvo hipótese de engano justificável”. Em tal aspecto foi feita uma crítica à interpretação jurisprudencial restritiva que se tem feito sobre esse comando, com teor praticamente negado por nossas Cortes que ainda entendem pela necessidade de prova da má-fé dos fornecedores e prestadores para a incidência do seu conteúdo.

Trata-se, na verdade, de uma interpretação extensiva e equivocada da antiga Súmula n. 153 do STF, segundo a qual "cobrança excessiva, mas de boa-fé, não dá lugar às sanções do art. 1.531 do Código Civil”. A ementa é do remoto ano de 1963 e o dispositivo citado, do Código Civil de 1916, equivale ao atual art. 940 do Código Civil de 2002, tratando da possibilidade de repetição em dobro dos valores indevidamente pagos nas relaçoôes civis. ${ }^{7}$ Ora, para as relações de consumo, notadamente diante do fato de ter o CDC adotado um sistema objetivo de responsabilização, não deveria ser cogitado o debate da má-fé. Entretanto, a jurisprudência ainda está apegada a uma antiga tradição, por ora superada.

No tocante ao prazo de prescrição subsumido ao caso, concluíram os juristas presentes que deveria incidir o lapso de dez anos, previsto no art. 205 do Código Civil, por ser mais favorável ao consumidor, em consonância com a teoria do diálogo das fontes. Cite-se, a esse propósito, que o Superior Tribunal de Justiça tem súmula estabelecendo que o consumidor tem esse prazo maior para repetir tarifas abusivas, como as de água e esgoto (Súmula 412). Houve, assim, certa contradição do julgamento em relação a essa súmula, com o devido respeito. Acrescente-se,

7 Era a redação do art. 1.531 do Código Civil de 1916: "Aquele que demandar por dívida já paga, no todo ou em parte, sem ressalvar as quantias recebidas, ou pedir mais do que for devido, ficará obrigado a pagar ao devedor, no primeiro caso, o dobro do que houver cobrado e, no segundo, o equivalente do que dele exigir, salvo se, por lhe estar prescrito o direito, decair da ação". O art. 940 do Código Civil de 2002 tem a seguinte previsão: "Aquele que demandar por dívida já paga, no todo ou em parte, sem ressalvar as quantias recebidas ou pedir mais do que for devido, ficará obrigado a pagar ao devedor, no primeiro caso, o dobro do que houver cobrado e, no segundo, o equivalente do que dele exigir, salvo se houver prescrição". 
como reflexão atualizada, que essa repetição de indébito mantém relação com a responsabilidade civil contratual, e, em junho de 2018, a própria Segunda Seção do STJ acabou por concluir pela aplicação do prazo geral de dez anos para as pretensões em situações tais. ${ }^{8}$

Não se pode negar o infeliz impacto social decorrente do julgamento, uma vez que as pessoas não mais procurarão - e, de fato, já não estão mais procurando - os negócios de financiamento da casa própria nos próximos anos, informadas por situaçôes injustas anteriores, de pagamento de montantes extorsivos e abusivos. Como tenho sustentado, os contratos de aquisição de imóveis na planta apresentam um extenso rol de claras abusividades impostas aos adquirentes, em regra consumidores.

Em corajoso e apurado estudo sobre a temática, Tatiana Bonatti Peres, Ana Beatriz Marchioni Kesselring e Alessandro Segalla demonstram a presença de pelo menos dezoito cláusulas ou práticas abusivas em tais contratos. 'São elas, representando verdadeiro abuso de direito por parte das construtoras e agentes financeiros que participam do contrato: a) atraso na entrega da obra; b) cláusula de tolerância pelo atraso; c) reajuste em caso de atraso na entrega; $d$ ) presença de danos morais

8 Em 27 de junho de 2018, a questão relativa ao prazo prescricional para a responsabilidade civil contratual foi pacificada na Segunda Seção do Tribunal da Cidadania, tendo prevalecido a tese pelo prazo de dez anos para a responsabilidade civil contratual decorrente do inadimplemento. Afastou-se a unificação de prazos que era seguida por julgados mais recentes da Terceira Turma. A afirmação se deu no julgamento dos Embargos de Divergência n. 1.280.825, de relatoria da Ministra Nancy Andrighi, que parece ter mudado seu entendimento anterior. Juntou-se ela aos Ministros da Quarta Turma da Corte, formando maioria, em face dos julgadores da Terceira Turma. Segundo a sua argumentação principal, a regra para os casos de descumprimento do contrato é a execução específica da obrigação, uma vez que "ao credor é permitido exigir do devedor o exato cumprimento daquilo que foi avençado. Se houver mora, além da execução específica da prestação, o credor pode pleitear eventuais perdas e danos. $\mathrm{Na}$ hipótese de inadimplemento definitivo, o credor poderá escolher entre a execução pelo equivalente ou a resolução da relação jurídica contratual. Em ambas alternativas, poderá requerer, ainda, o pagamento de perdas e danos". Sendo desse modo, existem três pretensões potenciais por parte do credor, o que exige do intérprete a aplicação das mesmas regras para as três pretensões: "não parece haver sentido jurídico nem lógica a afirmação segundo a qual o credor tem um prazo para exigir o cumprimento da obrigação e outro para reclamar o pagamento das perdas e danos". Diante desse cenário, entendeu-se que não havia razão para se entender pelo prazo de três anos para as pretensóes reparatórias por inadimplemento, raciocínio que também é preciso, juntando-se à argumentação aqui antes deduzida.

9 SEGALLA, Alessandro. Cláusulas abusivas comuns na aquisição de imóvel em construção e proteção do consumidor em juízo. In: ALVIM, Angélica Arruda; ALVIM, Eduardo Arruda; CHIAVASSA, Marcelo (Coord.). 25 anos do Código de Defesa do Consumidor: panorama atual e perspectivas futuras. Rio de Janeiro: GZ, 2017. 
pelo atraso; $e$ ) multas ou descontos excessivos em caso de resolução por inadimplemento; $f$ ) devolução do valor pago que não seja em dinheiro; $g$ ) devolução do valor pago somente após a conclusão da obra; $h$ ) cobrança de taxa em caso de cessão da posição contratual (contrato de gaveta); i) repasse de comissão, especialmente da antes comentada SATI; j) cobrança de "juros no pé", antes da entrega das chaves; $k$ ) correção pela tabela PRICE; $l$ ) entrega de área menor do que o prometido; $m$ ) não fixação de prazo para outorga da escritura definitiva; $n$ ) previsão de cláusula de eleição de foro e de arbitragem, em contrato de adesão e de consumo, sem os devidos destaques; o) presença de variadas formas de publicidade enganosa, enganando o consumidor; $p$ ) imposição de penalidades excessivas ao adquirente, sem reciprocidade; q) constituição de garantias desproporcionais sobre a área construída, pela construtora, capazes de colocar em risco as unidades adquiridas; e r) cobrança de constituição condominial antes da entrega das unidades.

Como palavras finais, o painel concluiu que tais negócios jurídicos são maléficos não só para as partes que os celebram, mas para toda a sociedade, contrariando os princípios da função social do contrato e da boa-fé objetiva, previstos nos arts. 421 e 422 do Código Civil. O desejo externado por todos foi no sentido da necessidade de maior intervenção do Poder Judiciário para corrigir esses desvios e abusividades.

\section{DIREITOS REAIS NA CONTEMPORANEIDADE. $O$ ENQUADRAMENTO DA MULTIPROPRIEDADE IMOBILIÁRIA}

A quarta mesa do XV Encontro dos Grupos de Pesquisas em Direito Civil foi dedicada às titularidades, ou seja, ao Direito das Coisas e aos Direito Reais. Participaram do painel os Professores Rodrigo da Guia, André Luiz Arnt Ramos, Rodrigo Toscano de Brito e Maurício Bunazar. A presidência e a condução dos debates foram do Professor Gustavo Andrade. O julgado escolhido tratou do enquadramento ou não da multipropriedade imobiliária ou "time-sharing" como direito real (STJ, REsp 1.546.165/SP, 3a Turma, Rel. Min. Ricardo Villas Bôas Cueva, Rel. p/acórdão Min. João Otávio de Noronha, j. 26.04.2016, DJe 06.09.2016).

A discussão envolve o art. 1.225 do Código Civil, que traz o rol dos direitos reais. A dúvida que sempre é colocada a respeito do preceito diz respeito à existência de um rol taxativo (numerus clausus) ou exemplificativo (numerus apertus). ${ }^{10}$

10 CC/2002. "Art. 1.225. São direitos reais: I - a propriedade; II - a superfície; III - as servidōes; IV - o usufruto; V - o uso; VI - a habitação; VII - o direito do promitente comprador do imóvel; VIII - o penhor; IX - a hipoteca; X - a anticrese. XI - a concessão de uso especial para fins de moradia; XII - a concessão de direito real de uso; e XIII - a laje.” 
Para a visão clássica, que ainda prevalece no Brasil, consubstanciadora de uma primeira e principal corrente doutrinária sobre o tema, a relação dos direitos reais é taxativa ou numerus clausus. Por todos os autores que assim entendem, afirma Orlando Gomes que "diz-se, por isto, que a constituição dos direitos reais obedece ao sistema do numerus clausus, ao contrário da formação dos contratos, na qual, vigorando o princípio da liberdade de estruturação do conteúdo, prevalece o sistema numerus apertus. Em consequência, toda limitação ao direito de propriedade que não esteja prevista na lei como direito real tem natureza obrigacional". ${ }^{11}$

$\mathrm{Na}$ minha leitura, entre os que sustentam que o rol não é taxativo, podem ser encontradas duas subcorrentes. Para a primeira, não haveria taxatividade dos direitos reais, mas sim tipicidade, uma vez que outras leis podem criar direitos reais; posição que defendo. ${ }^{12}$ Entretanto, há quem entenda não haver taxatividade ou tipicidade, pois a autonomia privada pode criar novos direitos reais. Seguindo a última visão, ensinam Cristiano Chaves de Farias e Nelson Rosenvald que "a rigidez na elaboração de tipos não é absoluta. Nada impede que o princípio da autonomia privada possa, no âmbito do conteúdo de cada direito real, ainda que em pequena escala, intervir para a afirmação de diferentes modelos jurídicos, com base nos espaços consentidos em lei. Desde que não exista lesão a normas de ordem pública, os privados podem atuar dentro dos tipos legais, utilizando a sua vontade criadora para inovar no território concedido pelo sistema jurídico, modificando o conteúdo dos direitos reais afirmados pela norma. Como exemplo, podemos citar a multipropriedade - tanto resultante da fusão da propriedade individual e coletiva nas convenções de condomínio, como aquela tratada na propriedade de shopping center, de flat ou time sharing." ${ }^{13}$ Como se pode notar, os últimos doutrinadores citam o exemplo do "time-sharing", que representa um sistema de multipropriedade fracionada entre pessoas distintas no tempo.

No acórdão prolatado pelo Superior Tribunal de Justiça, o Ministro Ricardo Villas Bôas Cueva julgou no sentido de ter o "time-sharing" natureza contratual, uma vez que "não se admite a criação de um direito real propriamente dito, devendo-se seguir os tipos reais previstos na legislação específica, especialmente os do Código Civil". Ainda segundo ele, "a adoção da forma livre de criação dos direitos

11 GOMES, Orlando. Direitos reais. Coord. Edvaldo Brito. Atualizador Luiz Edson Fachin. 19. ed. Rio de Janeiro: Forense, 2004, p. 21.

12 Ver: TARTUCE, Flávio. Direito civil: v. 4. Direito das coisas. 10. ed. Rio de Janeiro: Forense, 2018. Capítulo 1.

13 FARIAS, Cristiano Chaves; ROSENVALD, Nelson. Curso de direito civil: direitos reais. Rio de Janeiro: Lumen Juris, 2006, p. 12. 
reais seria capaz de promover um ambiente de insegurança jurídica aos negócios imobiliários devido à impossibilidade de se prever as formas variadas e criativas de novos direitos reais que surgiriam e os efeitos jurídicos que poderiam irradiar" (STJ, REsp 1.546.165/SP, 3a Turma, Rel. Min. Ricardo Villas Bôas Cueva, Rel. p/ acórdão Min. João Otávio de Noronha, j. 26.04.2016, DJe 06.09.2016).

Essa visão acabou por ser superada, pois prevaleceu o voto do Ministro João Otávio de Noronha, seguido pelos Ministros Paulo Dias Moura Ribeiro, Paulo de Tarso Sanseverino e Marco Aurélio Bellizze de Oliveira. De acordo com a tese prevalecente, o time-sharing deve ser tratado como direito real, o que não representaria ofensa à taxatividade dos direitos reais. Conforme a ementa do julgado, citando expressamente a melhor doutrina sobre a temática, "o sistema time-sharing ou multipropriedade imobiliária, conforme ensina Gustavo Tepedino, é uma espécie de condomínio relativo a locais de lazer no qual se divide o aproveitamento econômico de bem imóvel (casa, chalé, apartamento) entre os cotitulares em unidades fixas de tempo, assegurando-se a cada um o uso exclusivo e perpétuo durante certo período do ano. Extremamente acobertada por princípios que encerram os direitos reais, a multipropriedade imobiliária, nada obstante ter feição obrigacional aferida por muitos, detém forte liame com o instituto da propriedade, se não for sua própria expressão, como já vem proclamando a doutrina contemporânea, inclusive num contexto de não se reprimir a autonomia da vontade nem a liberdade contratual diante da preponderância da tipicidade dos direitos reais e do sistema de numerus clausus".

Ao final, entendeu-se que não haveria óbice para se dotar a multipropriedade imobiliária de um caráter real, mesmo sob a ótica da taxatividade dos direitos reais, diante da ausência de vedação ou proibição da existência de novas categorias com as suas características: "além disso, com os atributos dos direitos reais se harmoniza o novel instituto, que, circunscrito a um vínculo jurídico de aproveitamento econômico e de imediata aderência ao imóvel, detém as faculdades de uso, gozo e disposição sobre fração ideal do bem, ainda que objeto de compartilhamento pelos multiproprietários de espaço e turnos fixos de tempo. A multipropriedade imobiliária, mesmo não efetivamente codificada, possui natureza jurídica de direito real, harmonizando-se, portanto, com os institutos constantes do rol previsto no art. 1.225 do Código Civil; e o multiproprietário, no caso de penhora do imóvel objeto de compartilhamento espaço-temporal (time-sharing), tem, nos embargos de terceiro, o instrumento judicial protetivo de sua fração ideal do bem objeto de constrição" (STJ, REsp 1.546.165/SP, 3a Turma, Rel. Min. Ricardo Villas Bôas Cueva, Rel. p/ acórdão Min. João Otávio de Noronha, j. 26.04.2016, DJe 06.09.2016). 
O julgado foi festejado no encontro por ter adotado expressamente visão doutrinária de relevo sobre o assunto, fruto de um dos ícones da escola do Direito Civil Constitucional. Porém, com o devido respeito, o julgado merece críticas pelo fato de não ter ingressado diretamente na afirmação de ser o rol do art. 1.225 do Código Civil meramente exemplificativo. Apesar de ter sido dada uma interpretação extensiva ao comando, notadamente à menção à propriedade no inciso I do preceito, a verdade é que a multipropriedade não está expressa no rol do dispositivo. Além disso, não há qualquer norma jurídica que trate da categoria. Por isso, o julgamento não deixa de trazer a mim certa perplexidade.

\section{A PARENTALIDADE SOCIOAFETIVA APÓS A DECISÃO DO STF}

A quinta e penúltima mesa de debates do nosso encontro tratou do Direito de Família, sob a presidência e condução do Professor Alexandre Barbosa e a atuação dos palestrantes Vitor Almeida, Ricardo Calderón, Maria Rita de Holanda e Mário Luiz Delgado.

Foi estudado o julgado do Supremo Tribunal Federal do ano de 2016 em que se analisou repercussão geral sobre a parentalidade socioafetiva. Conforme a tese firmada nesse decisum, "a paternidade socioafetiva, declarada ou não em registro, não impede o reconhecimento do vínculo de filiação concomitante, baseada na origem biológica, com os efeitos jurídicos próprios" (Recurso Extraordinário n. 898.060/SC, Rel. Min. Luiz Fux, j. 21.09.2016, publicado no seu Informativo n. 840).

O julgamento dividiu opiniōes. Ricardo Calderón, por exemplo, festejou o seu conteúdo, pelas razões que desenvolvo a seguir. Maria Rita Holanda, por outra via, manifestou uma visão crítica, por entender que a afetividade foi derrotada no julgamento, conforme sustentado por José Fernando Simão em seus textos, uma vez que deveria prevalecer o voto do Ministro Edson Fachin, que entendeu pela prevalência da parentalidade socioafetiva.

Fiquei e permaneço com a primeira opinião. Isso porque, além de reconhecer a possibilidade de vínculos múltiplos parentais, uma das grandes contribuiçóes do aresto foi consolidar a posição de que a socioafetividade é forma de parentesco civil, em posição igualitária diante do parentesco consanguíneo. Nesse sentido, destaque-se o seguinte trecho do voto do Ministro Relator: "a compreensão jurídica cosmopolita das famílias exige a ampliação da tutela normativa a todas as formas pelas quais a parentalidade pode se manifestar, a saber: (i) pela presunção decorrente do casamento ou outras hipóteses legais; (ii) pela descendência biológica; 
ou (iii) pela afetividade. A evolução científica responsável pela popularização do exame de DNA conduziu ao reforço de importância do critério biológico, tanto para fins de filiação quanto para concretizar o direito fundamental à busca da identidade genética, como natural emanação do direito de personalidade de um ser. A afetividade enquanto critério, por sua vez, gozava de aplicação por doutrina e jurisprudência desde o Código Civil de 1916 para evitar situaçóes de extrema injustiça, reconhecendo-se a posse do estado de filho, e consequentemente o vínculo parental, em favor daquele que utilizasse o nome da família (nominatio), fosse tratado como filho pelo pai (tractatio) e gozasse do reconhecimento da sua condição de descendente pela comunidade (reputatio)".

Houve, além disso, a afirmação, feita por vários Ministros, de ser a afetividade um valor jurídico e um princípio inerente à ordem civil-constitucional brasileira, como é defendido por Ricardo Calderón. ${ }^{14}$ Afirmou-se, igualmente, que a parentalidade socioafetiva, como forma de parentesco civil, está em situação de igualdade com a parentalidade biológica. Em outras palavras, não há hierarquia entre uma e outra modalidade de filiação, o que representa um razoável equilíbrio, como bem ponderou Calderón no painel.

Por fim, concretizou-se a vitória da multiparentalidade, que passou a ser admitida pelo Direito Brasileiro, mesmo que contra a vontade do pai socioafetivo ou do pai biológico, fazendo-se uma leitura inversa da tese final decorrente do julgamento. Ficou claro, pelo acórdão superior, que o reconhecimento do vínculo concomitante é para todos os fins, inclusive alimentares e sucessórios. Como apontado por todos os pesquisadores presentes no encontro, grandes são os desafios que derivam dessa afirmação. ${ }^{15}$

14 CALDERÓN, Ricardo. O princípio da afetividade no direito de família. 2. ed. Rio de Janeiro: Forense, 2017.

15 A respeito da possibilidade do vínculo concomitante, destaque-se que o Ministro Fux utilizou como paradigma um caso julgado nos Estados Unidos da América. Foram suas palavras: “a pluriparentalidade, no Direito Comparado, pode ser exemplificada pelo conceito de 'dupla paternidade' (dual paternity), construído pela Suprema Corte do Estado da Louisiana, EUA, desde a década de 1980 para atender, ao mesmo tempo, ao melhor interesse da criança e ao direito do genitor à declaração da paternidade. Doutrina. Os arranjos familiares alheios à regulação estatal, por omissão, não podem restar ao desabrigo da proteção a situações de pluriparentalidade, por isso que merecem tutela jurídica concomitante, para todos os fins de direito, os vínculos parentais de origem afetiva e biológica, a fim de prover a mais completa e adequada tutela aos sujeitos envolvidos, ante os princípios constitucionais da dignidade da pessoa humana (art. 10, III) e da paternidade responsável (art. 226, \$ 70)” (STF, RE 898.060/SC, Tribunal Pleno, Rel. Min. Luiz Fux, j. 21.09.2016). 
Como problema criado pelo julgamento, e ora apontado pela mesa do encontro, a tese firmada acaba por possibilitar que os filhos acionem os pais biológicos para obter o vínculo de filiação com intuitos alimentares e sucessórios, em claras demandas frivolas, com finalidade patrimonial pura. Seguiu-se, assim, o caminho que já vinha sendo percorrido pelo Superior Tribunal de Justiça, e muito criticado pela doutrina. ${ }^{16}$ Esse foi um dos pontos negativos da premissa fixada, concluindo os juristas presentes que tais demandas devem ser sempre evitadas pelo Poder Judiciário.

De fato, a tese adotada pelo Supremo Tribunal Federal possibilita tal injusto e infeliz caminho, tendo sido utilizado como argumento o princípio constitucional da paternidade responsável. Nos termos do voto do Relator, Ministro Luiz Fux, "a paternidade responsável, enunciada expressamente no art. 226, $\$ 7$ o da Constituição, na perspectiva da dignidade humana e da busca pela felicidade, impõe o acolhimento, no espectro legal, tanto dos vínculos de filiação construídos pela relação afetiva entre os envolvidos quanto daqueles originados da ascendência biológica, sem que seja necessário decidir entre um ou outro vínculo quando o melhor interesse do descendente for o reconhecimento jurídico de ambos" (decisão publicada no Informativo n. 840 do STF). Ressalve-se, ao contrário da posição anterior do Superior Tribunal de Justiça, que, em casos de concomitância de vínculos, deve ser mantido o vínculo com o pai socioafetivo e incluído o pai biológico ou vice-versa.

16 Sobre a posição do Superior Tribunal de Justiça, veja-se o acórdão anterior publicado no Informativo n. 512 da Corte, com o seguinte trecho: "é possível o reconhecimento da paternidade biológica e a anulação do registro de nascimento na hipótese em que pleiteados pelo filho adotado conforme prática conhecida como 'adoção à brasileira'. A paternidade biológica traz em si responsabilidades que lhe são intrínsecas e que, somente em situaçôes excepcionais, previstas em lei, podem ser afastadas. O direito da pessoa ao reconhecimento de sua ancestralidade e origem genética insere-se nos atributos da própria personalidade. A prática conhecida como 'adoção à brasileira', ao contrário da adoção legal, não tem a aptidão de romper os vínculos civis entre o filho e os pais biológicos, que devem ser restabelecidos sempre que o filho manifestar o seu desejo de desfazer o liame jurídico advindo do registro ilegalmente levado a efeito, restaurando-se, por conseguinte, todos os consectários legais da paternidade biológica, como os registrais, os patrimoniais e os hereditários. Dessa forma, a filiação socioafetiva desenvolvida com os pais registrais não afasta os direitos do filho resultantes da filiação biológica, não podendo, nesse sentido, haver equiparação entre a 'adoção à brasileira' e a adoção regular. Ademais, embora a 'adoção à brasileira', muitas vezes, não denote torpeza de quem a pratica, pode ela ser instrumental de diversos ilícitos, como os relacionados ao tráfico internacional de crianças, além de poder não refletir o melhor interesse do menor. Precedente citado: REsp 833.712-RS, DJ 4/6/2007” (STJ, REsp 1.167.993/RS, Rel. Min. Luis Felipe Salomão, j. 18.12.2012). 


\section{O RECONHECIMENTO DA INCONSTITUCIONALIDADE DO ART. 1.790 DO CÓDIGO CIVIL}

A sexta e última mesa do XV Encontro dos Grupos de Pesquisas em Direito Civil tratou do Direito das Sucessões. A presidência dos trabalhos foi da Professora Débora Brandão e contou com a presença dos pesquisadores Daniela Teixeira, Marília Xavier, Fabíola Lôbo e Cláudia Stein Vieira como palestrantes. Como não poderia ser diferente, analisou-se o julgamento do Supremo Tribunal Federal sobre a inconstitucionalidade do art. 1.790 do Código Civil, que tratava da sucessão do companheiro. ${ }^{17}$ Por maioria de votos, entendeu-se pela equiparação sucessória total entre o casamento e a união estável, para os fins de repercussão geral (STF, Recurso Extraordinário n. 878.694/MG, Rel. Min. Luís Roberto Barroso, publicado no seu Informativo n. 864). Nos termos do voto do relator, "não é legítimo desequiparar, para fins sucessórios, os cônjuges e os companheiros, isto é, a família formada pelo casamento e a formada por união estável. Tal hierarquização entre entidades familiares é incompatível com a Constituição".

Quando da realização do evento, o acórdão ainda não havia sido publicado, mas já se tinha o fim do julgamento. Oportuno lembrar que, na primeira votação, no ano de 2016, foram sete votos concluindo pela inconstitucionalidade da norma em face do Texto Maior. Além do Relator, concluíram dessa forma os Ministros Luiz Edson Fachin, Teori Zavascki, Rosa Weber, Luiz Fux, Celso de Mello e Cármen Lúcia. Sucessivamente, houve pedido de vista do Ministro Dias Toffoli. A tese então fixada, que acabou sendo mantida para os devidos fins de repercussão geral, foi a seguinte: "no sistema constitucional vigente, é inconstitucional a distinção de regimes sucessórios entre cônjuges e companheiros, devendo ser aplicado, em ambos os casos, o regime estabelecido no art. 1.829 do CC/2002".

Após pedido de vista do Ministro Dias Toffoli, o processo retomou seu destino em 2017, tendo esse julgador concluído pela constitucionalidade da norma, pois haveria justificativa constitucional para o tratamento diferenciado entre o casamento e a união estável (voto prolatado em 30 de março de 2017). O Ministro

17 CC/2002. "Art. 1.790. A companheira ou o companheiro participará da sucessão do outro, quanto aos bens adquiridos onerosamente na vigência da união estável, nas condiçôes seguintes: I - se concorrer com filhos comuns, terá direito a uma quota equivalente à que por lei for atribuída ao filho; II - se concorrer com descendentes só do autor da herança, tocar-lhe-á a metade do que couber a cada um daqueles; III - se concorrer com outros parentes sucessíveis, terá direito a um terço da herança; IV - não havendo parentes sucessíveis, terá direito à totalidade da herança." 
Marco Aurélio pediu nova vista, unindo também o julgamento do Recurso Extraordinário n. 646.721/RS, que tratava da sucessão de companheiro homoafetivo, do qual era Relator (Tema 498).

Em maio de 2017 foram retomados de forma definitiva os julgamentos das duas demandas, iniciando-se pela última. O Ministro Marco Aurélio apontou não haver razão para a distinção entre a união estável homoafetiva e a união estável heteroafetiva, na linha do que fora decidido pela própria Corte quando da análise da ADPF 132, oriunda no Estado do Rio de Janeiro, em 2011. Porém, no que concerne ao tratamento diferenciado da união estável diante do casamento, asseverou não haver qualquer inconstitucionalidade, devendo ser preservado o teor do art. 1.790 do Código Civil, na linha do que consta do art. 226, $\$ 3^{\circ}$, do Texto Maior, que, ao tratar da conversão da união estável em casamento, reconheceu uma hierarquia entre as duas entidades familiares.

Ao final, o Ministro Marco Aurélio restou vencido, prevalecendo a posição dos Ministros Luís Roberto Barroso, Luiz Edson Fachin, Rosa Weber, Luiz Fux, Celso de Mello, Cármen Lúcia e Alexandre de Moraes. Frise-se que o último julgador não votou no processo anterior - pois ainda era magistrado o Ministro Teori Zavascki -, mas prolatou sua visão na demanda envolvendo a sucessão homoafetiva. Com o Relator, apenas votou o Ministro Ricardo Lewandowski, que adotou a premissa in dubio pro legislatore.

Em suma, o placar do julgamento do Tema 498 foi de 7 votos a 2, ausentes os Ministros Dias Toffoli e Gilmar Mendes. Conforme consta da publicação inserida no sempre citado Informativo n. 864 da Corte, "o Supremo Tribunal Federal (STF) afirmou que a Constituição prevê diferentes modalidades de família, além da que resulta do casamento. Entre essas modalidades, está a que deriva das uniōes estáveis, seja a convencional, seja a homoafetiva. Frisou que, após a vigência da Constituição de 1988, duas leis ordinárias equipararam os regimes jurídicos sucessórios do casamento e da união estável (Lei 8.971/1994 e Lei 9.278/1996). O Código Civil, no entanto, desequiparou, para fins de sucessão, o casamento e as uniões estáveis. Dessa forma, promoveu retrocesso e hierarquização entre as famílias, o que não é admitido pela Constituição, que trata todas as famílias com o mesmo grau de valia, respeito e consideração. $\mathrm{O}$ art. 1.790 do mencionado código é inconstitucional, porque viola os princípios constitucionais da igualdade, da dignidade da pessoa humana, da proporcionalidade na modalidade de proibição à proteção deficiente e da vedação ao retrocesso".

Quanto ao processo original, o que iniciou o julgamento da questão (Recurso Extraordinário n. 878.694/MG) apenas confirmou o que estava consolidado 
desde 2016, entendendo pela constitucionalidade do art. 1.790 do Código Civil os Ministros Marco Aurélio e Ricardo Lewandowski, e mantendo-se a coerência de posições com a demanda anterior. Neste primeiro processo, o placar foi de 7 a 3, ausente novamente o Ministro Gilmar Mendes (Tema 809). Mais uma vez, conforme consta do Informativo n. 864 do STF, "o Supremo Tribunal Federal afirmou que a Constituição contempla diferentes formas de família, além da que resulta do casamento. Nesse rol incluem-se as famílias formadas mediante união estável. Portanto, não é legítimo desequiparar, para fins sucessórios, os cônjuges e os companheiros, isto é, a família formada por casamento e a constituída por união estável. Tal hierarquização entre entidades familiares mostra-se incompatível com a Constituição. O art. 1.790 do Código Civil de 2002, ao revogar as Leis 8.971/1994 e 9.278/1996 e discriminar a companheira (ou companheiro), dando-lhe direitos sucessórios inferiores aos conferidos à esposa (ou ao marido), entra em contraste com os princípios da igualdade, da dignidade da pessoa humana, da proporcionalidade na modalidade de proibição à proteção deficiente e da vedação ao retrocesso".

Todos os presentes na última mesa do nosso evento elogiaram a premissa final de equiparação, ressaltando as contribuições doutrinárias citadas no acórdão, notadamente de Zeno Veloso e Giselda Hironaka. Todavia, também restou pacificado no painel que a grande dúvida deixada pelo julgamento diz respeito à afirmação de ser ou não o companheiro herdeiro necessário. Conforme salientado pelos juristas presentes, do voto do Ministro Roberto Barroso a resposta parece ser positiva, em contraste com o voto do Ministro Edson Fachin, que se expressou em sentido contrário. O Professor Paulo Lôbo manifestou a sua opinião, no sentido de seguir a primeira visão, sendo seguido por outros professores presentes, como Giselda Hironaka, João Aguirre e por mim mesmo. Como tem sido costume, Mário Luiz Delgado discordou desse entendimento, sustentando não ser o convivente herdeiro reservatário, pois caso contrário a união estável passaria a ser um casamento forçado.

Houve, ainda, um interessante debate sobre a modulação dos efeitos do decisum, na linha das palavras do Ministro Roberto Barroso, a saber: "é importante observar que o tema possui enorme repercussão na sociedade, em virtude da multiplicidade de sucessões de companheiros ocorridas desde o advento do CC/2002. Assim, levando-se em consideração o fato de que as partilhas judiciais e extrajudiciais que versam sobre as referidas sucessões encontram-se em diferentes estágios de desenvolvimento (muitas já finalizadas sob as regras antigas), entendo ser recomendável modular os efeitos da aplicação do entendimento ora afirmado. Assim, com o intuito de reduzir a insegurança jurídica, entendo que a solução ora alcançada 
deve ser aplicada apenas aos processos judiciais em que ainda não tenha havido trânsito em julgado da sentença de partilha, assim como às partilhas extrajudiciais em que ainda não tenha sido lavrada escritura pública" (STF, Recurso Extraordinário n. 878.694/MG, Rel. Min. Luís Roberto Barroso). Alguns dos presentes expuseram situaçōes concretas em que tais conclusões podem ser mostrar injustas, o que, sem dúvida, é uma realidade.

De todo modo, parecem ter sido majoritárias as conclusóes de que o julgamento representou um avanço e que dele deve decorrer a afirmação de que o convivente é herdeiro necessário, devendo ter a proteção da legítima. Como consequência, alguns efeitos podem ser destacados, a saber: a) incidência das regras previstas entre os arts. 1.846 e 1.849 do CC/2002 para o companheiro, o que gera restrições na doação e no testamento, uma vez que o convivente deve ter a sua legítima protegida, como herdeiro reservatário; $b$ ) o companheiro passa a ser incluído no art. 1.974 do Código Civil, para os fins de rompimento de testamento, caso ali também se inclua o cônjuge; e $c$ ) o convivente tem o dever de colacionar os bens recebidos em antecipação (arts. 2.002 a 2.012 do CC), sob pena de sonegados (arts. 1.992 a 1.996), caso isso igualmente seja reconhecido ao cônjuge.

No que concerne ao direito real de habitação do companheiro, também não mencionado nos julgamentos, não resta dúvida da sua existência, na linha do que vinham reconhecendo a doutrina e a jurisprudência superior. Mas qual a extensão desse direito real de habitação ao companheiro? Terá o direito porque subsiste no sistema o art. $7^{\circ}$, parágrafo único, da Lei n. 9.278/1996, na linha do último julgado? Ou lhe será reconhecido esse direito real de forma equiparada ao cônjuge, por força do art. 1.831 do Código Civil? O Supremo Tribunal Federal não enunciou expressamente essa questão, apesar de tender à última resposta, cabendo à doutrina e à própria jurisprudência ainda resolvê-la.

Por derradeiro, debatemos no evento se a equiparação sucessória feita pelo Supremo Tribunal Federal incluiria os devidos fins familiares, sendo, portanto, total. Em nosso encontrou surgiu uma visão interessante, sustentada por Anderson Schreiber e Ana Luiza Nevares, no sentido de haver equiparação das duas entidades familiares somente para os fins de normas de solidariedade, caso das regras sucessórias, de alimentos e de regime de bens. Em relação às normas de formalidade, como as relativas à existência formal da união estável e do casamento, aos requisitos para a ação de alteração do regime de bens do casamento e às exigências de outorga conjugal, a equiparação não deve ser total.

Esse entendimento doutrinário acabou por gerar a aprovação do Enunciado n. 641, na VIII Jornada de Direito Civil, em 2018: "a decisão do Supremo Tribunal 
Federal que declarou a inconstitucionalidade do art. 1.790 do Código Civil não importa equiparação absoluta entre o casamento e a união estável. Estendem-se à união estável apenas as regras aplicáveis ao casamento que tenham por fundamento a solidariedade familiar. Por outro lado, é constitucional a distinção entre os regimes, quando baseada na solenidade do ato jurídico que funda o casamento, ausente na união estável”. Em suma, mais uma vez, os debates foram profícuos, influenciando o surgimento e a consolidação de uma nova tese, que ganhou grande prestígio um ano depois.

\section{CONCLUSÕES}

Como este artigo demonstrou, a visão doutrinária muitas vezes tem se mostrado diferente da jurisprudência brasileira, e vice-versa, notadamente quanto às conclusôes sobre os fatos sociais. Porém, essa diferenciação de ideias não pode representar um isolamento ou apartheid quanto aos debates entre uns e outros. A democracia cresce com o embate na divergência e com as deduções que decorrem desse enfrentamento das discussões.

Com o fim de intensificar essa interação entre doutrina e jurisprudência, concebemos, em conjunto de esforços, o XV Encontro dos Grupos de Pesquisas em Direito Civil a partir da análise crítica de julgados recentes, do Superior Tribunal de Justiça e do Supremo Tribunal Federal, de grande impacto para o Direito Civil Contemporâneo. Em todos os sete painéis, as discussóes demonstram olhares muito além do que foi pronunciado nos acórdãos escolhidos, o que muito contribui para o aprofundamento dos temas correlatos.

As divergências são salutares para o avanço de toda a ciência jurídica nacional. Muitas vezes esquecida por estudiosos e julgadores, é preciso aproximar a doutrina da jurisprudência, como foi feito no evento. O lançamento deste livro, fruto dos nossos debates, igualmente contribui para a intensificação desse approach. Outras obras devem surgir na mesma linha, como o caso do recente trabalho Direito civil: diálogos entre a doutrina e a jurisprudência, que coordeno com o Ministro Luis Felipe Salomão, do Superior Tribunal de Justiça (Editora Atlas, 2018).

Compartilhando um pouco dessa outra experiência, trata-se de uma obra coletiva inédita, sem precedentes no meio editorial jurídico brasileiro, concebida por meio de artigos científicos compartilhados, em uma composição cega, sem que um autor visse antecipadamente o que foi desenvolvido pelo outro. A obra foi estruturada em quinze capítulos, em temas polêmicos que são debatidos por doutrinadores - autores de obras de importância para o Direito Privado nacional - e 
julgadores - Ministros do Superior Tribunal de Justiça e Desembargadores de Tribunais de Justiça -, em textos separados. Muitos dos julgadores são doutrinadores, pela sua grande contribuição para a ciência jurídica, e vice-versa, pois alguns doutrinadores também desenvolvem a atividade de magistrados.

Como temas contemporâneos de destaque, escolhemos os seguintes, de acordo com a ordem de tratamento no Código Civil: a) adequação de sexo do transexual; $b$ ) direito ao esquecimento; $c$ ) questôes polêmicas sobre a prescrição; $d$ ) boa-fé objetiva nos contratos; $e$ ) função social do contrato; $f$ ) contrato de seguro-saúde; g) responsabilidade objetiva na atualidade; $h$ ) critérios para a quantificação dos danos morais; i) novos danos na responsabilidade civil (danos morais coletivos, danos sociais ou difusos e danos por perda de uma chance); $j$ ) função social da posse e da propriedade; $k$ ) questôes polêmicas quanto ao condomínio edilício; l) parentalidade socioafetiva e multiparentalidade; $m$ ) alimentos entre os cônjuges; n) polêmicas na sucessão do cônjuge; e o) a inconstitucionalidade do art. 1.790 do Código Civil. Alguns assuntos são comuns ao nosso encontro ora relatado, como se pode notar.

Entre os doutrinadores, foram convidados, em ordem alfabética: Anderson Schreiber, Bruno Miragem, Carlos Roberto Gonçalves, Claudia Lima Marques, Giselda Maria Fernandes Novaes Hironaka, Gustavo Tepedino, José Fernando Simão, Mário Luiz Delgado, Nelson Rosenvald, Pablo Stolze Gagliano, Paulo Lôbo, Rodolfo Pamplona Filho, Rolf Madaleno, Zeno Veloso, além da minha participação. Entre os julgadores, aceitaram o convite, também em ordem alfabética: Desembargador Cláudio Luiz Bueno de Godoy (TJSP), Desembargador Ênio Santarelli Zuliani (TJSP), Desembargador Jones Figueirêdo Alves (TJPE), Ministro Marco Aurélio Bellizze (STJ), Desembargador Marco Aurélio Bezerra de Melo (TJRJ), Ministro Marco Aurélio Gastaldi Buzzi (STJ), Ministro Paulo de Tarso Sanseverino (STJ), Ministro Paulo Dias de Moura Ribeiro (STJ), Ministro Ricardo Villas Bôas Cueva (STJ), Desembargador Ronei Danielli (TJSC), Ministro Ruy Rosado de Aguiar Júnior (STJ, aposentado), Desembargador Sergio Cavalieri Filho (TJRJ, aposentado), Ministro Sidnei Beneti (STJ, aposentado) e Desembargador Sílvio Venosa (TJSP, aposentado) - em texto escrito em coautoria com a advogada Cláudia Rodrigues. Também entre os julgadores, há artigo do coordenador, Ministro Luis Felipe Salomão, em texto escrito com a assessora do Superior Tribunal de Justiça Ivoney Severina de Melo Pereira do Nascimento.

Além das obras jurídicas que buscam esse diálogo, há muito tempo tenho destacado a necessidade de maior interação entre a doutrina e a jurisprudência em eventos e encontros jurídicos. Muitas vezes, tais diálogos ocorrem nas já consagradas 
Jornadas de Direito Civil, realizadas pelo Conselho da Justiça Federal desde 2002, que têm contado com a crescente participação de Ministros dos Tribunais Superiores e de julgadores de primeiro e de segundo grau nos últimos anos. Mas ainda é muito pouco, pois precisamos de mais oportunidades para esses embates. Espero que isso ocorra nos próximos anos, sendo os congressos do Instituto Brasileiro de Direito Civil (IBDCIVIL) foro dos mais apropriados para a ampliação das experiências que demonstrei neste texto.

\section{REFERÊNCIAS}

ALEXY, Robert. Teoria dos direitos fundamentais. São Paulo: Malheiros, 2008.

CALDERÓN, Ricardo. O princípio da afetividade no direito de família. 2. ed. Rio de Janeiro: Forense, 2017.

FARIAS, Cristiano Chaves; ROSENVALD, Nelson. Curso de direito civil: direitos reais. Rio de Janeiro: Lumen Juris, 2006.

GOMES, Orlando. Direitos reais. Coord. Edvaldo Brito. Atualizador Luiz Edson Fachin. 19. ed. Rio de Janeiro: Forense, 2004.

LOPES, Lucas Miotto. Eu não quero saber! Uma defesa do direito de não saber como independente do direito à privacidade. Revista Direito, Estado e Sociedade, Rio de Janeiro: PUCRJ, p. 82-97, 2014.

SALOMÃO, Luis Felipe; TARTUCE, Flávio. Direito civil: diálogos entre a doutrina e a jurisprudência. São Paulo: Atlas, 2018.

SEGALLA, Alessandro. Cláusulas abusivas comuns na aquisição de imóvel em construção e proteção do consumidor em juízo. In: ALVIM, Angélica Arruda; ALVIM, Eduardo Arruda; CHIAVASSA, Marcelo (Coord.). 25 anos do Código de Defesa do Consumidor: panorama atual e perspectivas futuras. Rio de Janeiro: GZ, 2017.

TARTUCE, Flávio. Direito civil: v. 4. Direito das coisas. 10. ed. Rio de Janeiro: Forense, 2018. 
